\title{
Penerapan Arsitektur Multi-Tier Pada Sistem Informasi Akademik (SIA) Sma Negeri 7 Prabumulih
}

\author{
Mutiara Pasha ${ }^{1}$, Ahmad Haidar Mirza*2, Ria Andryani ${ }^{3}$ \\ ${ }^{2}$ Informatics Departement, Bina Darma University, Palembang, Indonesia \\ 1,3Information System Departement, Bina Darma University, Palembang, Indonesia \\ Email:1mutiarapasha95@gmail.com, 2haidarmirza@gmail.com, 3ria.andryani@binadarma.ac.id
}

\begin{abstract}
Abstrak
Aktivitas akademik yang terdapat pada SMA Negeri 7 Prabumulih adalah pengelolahan data siswa, data guru, data jadwal, data nilai dan data absensi. Dalam pengelolaan data akademik masih terdapat beberapa permasalahan yang kerap muncul yakni mengenai kesulitan yang dialami pihak sekolah dalam melakukan pengolahan data akademik karena belum di dokumentasikan secara elektronik oleh pihak sekolah. Maka untuk dapat menunjang efektifitas dan efisiensi serta mempermudah dalam melakukan pengelolaan data akademik pada SMA Negeri 7 Prabumulih, akan dibangun sistem informasi akademik dengan menerapkan arsitektur Multi-Tier merupakan Aplikasi Server yang dapat mengakses aplikasi Server lain untuk mendapatkan data dari data server dan mensuplai servis ke Client Application. Kelebihan arsitektur Multi-Tier logika bisnis pada middle tier dapat digunakan lagi untuk mengembangkan aplikasi client lain, sehingga mengurangi besarnya program untuk mengembangkan aplikasi lain. Selain itu meringankan beban pada tiap-tiap mesin karena program terdistribusi pada beberapa mesin.
\end{abstract}

Kata Kunci: Sistem, Informasi, Akademik, Multi-Tier

\section{PENDAHULUAN}

Pada era globalisasi saat ini, ilmu pengetahuan dan teknologi telah berkembang sangat pesat, khususnya dibidang teknologi informasi yang merambah di segala bidang. Perkembangan Teknologi Informasi yang disertai perkembangan internet saling mendukung satu sama lain sehingga melahirkan konsep Teknologi Informasi berbasis internet yang perkembangannya semakin luas dan semakin banyak diterapkan pada instansi pendidikan di berbagai bidang, demi tercapainya tujuan yang diinginkan. Teknologi internet sudah terbukti merupakan salah satu media informasi yang 


\section{Journal of Software Engineering Ampera}

Vol. 1, No. 3, October 2020 e-ISSN: 2775-2488

https://journal-computing.org/index.php/journal-sea/index

efektif dan efisien dalam penyebaran informasi yang dapat diakses oleh siapa saja, kapan saja dan dimana saja. Salah satu teknologi internet yang banyak diterapkan oleh pihak sekolah adalah sistem informasi akademik.

Sistem Informasi Akademik merupakan perangkat lunak yang digunakan untuk menyajikan informasi dan menata administrasi yang berhubungan dengan kegiatan akademis. Dengan menggunakan perangkat lunak seperti ini diharapkan kegiatan administrasi akademis dapat dikelola dengan baik dan informasi yang diperlukan dapat diperoleh dengan mudah dan cepat. Sistem informasi akademik pada instansi pendidikan dapat mendukung proses pengolahan data dan penyediaan informasi yang lengkap, cepat dan akurat mengenai data akademik.

SMA Negeri 7 Prabumulih merupakan salah satu sekolah di kabupaten Prabumulih yang belum mengadopsi sistem informasi akademik berbasis web. Sistem Informasi Akademik dapat memberikan layanan informasi yang berupa data dalam hal yang berhubungan dengan akademik. Dimana dalam hal ini pelayanan yang diberikan yaitu seperti : penyimpanan data untuk siswa baru, penentuan kelas, penentuan jadwal pelajaran, pembuatan jadwal mengajar, pembagian wali kelas dan proses penilaian. Sistem informasi akademik dapat mendukung proses pengolahan data dan penyediaan informasi yang lengkap, cepat dan akurat, dengan pengelolaan data secara integrasi sehingga data akan selalu up-to-date dan selalu siap digunakan, serta mengurangi resiko duplikasi data. Oleh karena itu kebutuhan akan teknologi tersebut sangat penting bagi SMA Negeri 7 Prabumulih utuk menyelesaikan pekerjaan dengan cepat dan memperoleh informasi yang tepat.

Aktivitas akademik yang terdapat pada SMA Negeri 7 Prabumulih adalah pengelolahan data siswa, data guru, data jadwal, data nilai dan data absensi. Dalam pengelolaan data akademik masih terdapat beberapa permasalahan yang kerap muncul yakni mengenai kesulitan yang dialami pihak sekolah dalam melakukan pengolahan data akademik karena belum di dokumentasikan secara elektronik oleh pihak sekolah, belum ada sistem rapor elektronik sehingga data rapor siswa akan melalui lebih banyak tahapan sebelum bisa dilihat oleh siswa yaitu harus melalui tahapan dari guru mata pelajaran mengkoreksi hasil ujian, merekap nilai, lalu diserahkan kepada wali kelas lalu wali kelas masih harus memverifikasi nilai masing-masing siswa lalu di cap di tata usaha, dengan dibangunnya sistem ini dapat memudahkan guru maupun siswa dalam melihat hasil rapor karena setiap siswa rata-rata sudah 


\section{Journal of Software Engineering Ampera}

Vol. 1, No. 3, October 2020 e-ISSN: 2775-2488

https://journal-computing.org/index.php/journal-sea/index

memiliki peralatan yang sudah mendukung untuk akses internet yang digunakan pada sistem ini.

Melihat permasalahan tersebut, solusi yang diberikan penulis untuk dapat menunjang efektifitas dan efisiensi serta mempermudah dalam melakukan pengelolaan data akademik pada SMA Negeri 7 Prabumulih, maka akan dibangun sistem informasi akademik dengan menerapkan arsitektur MultiTier merupakan Aplikasi Server yang dapat mengakses aplikasi server lain untuk mendapatkan data dari data server dan mensuplai servis ke Client Application. [2]. Pada penelitian terdahulu Anindya (2012) yang berjudul "Implementasi Arstitektur Multi-tier Dalam Perancangan Aplikasi Koperasi Simpan Pinjam". Menjelaskan Arsitektur multi-tier sebagai sebuah arsitektur aplikasi yang memiliki komponen software yang berbeda, terorganisasi pada tiers, menyediakan fungsi yang terdedikasi. Sebuah arsitektur multi-tier adalah arsitektur tiga-tingkat yang terdiri dari manajemen data layer (kebanyakan meliputi satu atau beberapa database server), Business Logic dan Presentation Tier (fungsi UI).

Arstitektur Multi-tier membutuhkan pemisahan lapisan kerja untuk membagi fungsionalitas, komponen dan kode proyek ke dalam tier (tingkatan) yang terpisah. Pendekatan ini menghasilkan suatu aplikasi yang dapat diperluas dan dapat dengan mudah dikelola serta dikembangkan setelah jangka waktu tertentu. Alasan mengapa menggunakan arsitektur Multi-Tier karena memiliki kelebihan logika bisnis pada middle-tier dapat digunakan lagi untuk mengembangkan aplikasi client lain, sehingga mengurangi besarnya program untuk mengembangkan aplikasi lain. Selain itu meringankan beban pada tiaptiap mesin karena program terdistribusi pada beberapa mesin [3].

\section{METODOLOGI PENELITIAN}

Pada bagian ini, penulis akan menguraikan sejumlah hal yang digunakan dalam pelaksanaan penelitian ini, antara lain: 1) Metode penelitian, 2) Metode pengumpulan data, dan 3) Metode pengembangan sistem atau perangkat lunak.

\subsection{Metode Penelitian}

Metode yang digunakan oleh penulis adalah metode deskriptif atau dikenal dengan metode survei. Metode deskriptif adalah suatu metode penelitian 


\section{Journal of Software Engineering Ampera}

Vol. 1, No. 3, October 2020 e-ISSN: 2775-2488

https://journal-computing.org/index.php/journal-sea/index

yang menggambarkan semua data atau keadaan obyek penelitian (seseorang, lembaga, masyarakat dan lain-lain) kemudian dianalisis dan dibandingkan berdasarkan kenyataan yang sedang berlangsung pada saat ini dan selanjutnya mencoba untuk memberikan pemecahan masalahnya. Penelitian deskriptif mempelajari masalah-masalah dalam masyarakat, baik itu menyangkut tata cara, situasi hubungan, sikap perilaku, cara pandang dan pengaruh-pengaruh dalam suatu kelompok masyarakat. [4].

\subsection{Metode Pengumpulan Data}

Metode pengumpulan data digunakan untuk membantu dalam pembuatan sistem informasi akademik beserta laporan penelitian, Adapun metode pengumpulan data yang penulis gunakan dalam penulisan skripsi ini adalah sebagai berikut :

1) Pengamatan (Observasi)

Penulis melakukan pengamatan secara langsung kepada objek penelitian yaitu SMA Negeri 7 Prabumulih tentang pelaksanaan dari kegiatan operasional, mengutip catatan, laporan serta dokumen yang dipakai oleh SMA Negeri 7 Prabumulih dan merupakan data penunjang dalam proses analisa masalah yang akan dibahas.

2) Wawancara (Interview)

Penulis mengadakan tanya jawab atau berdialog secara langsung dengan salah satu pihak staff yaitu tata usaha pada SMA Negeri 7 Prabumulih yang berisikan pertanyaan yang berhubungan dengan data-data yang dibutuhkan.

3) Studi Kepustakaan (Study Literatur)

Mengumpulkan data dengan mempelajari masalah yang berhubungan dengan objek yang diteliti serta bersumber dari buku-buku pedoman, literatur-literatur yang disusun oleh para ahli untuk melengkapi data yang diperlukan dalam penelitian ini.

\subsection{Metode Pengembangan Sistem}

Adapun metode pengembangan sistem yang penulis gunakan dalam penulisan proposal penelitian ini adalah Waterfall merupakan model klasik yang bersifat sistematis, berurutan dalam membangun software, dengan melalui beberapa tahapan penelitian [5]. Berikut fase-fase dalam model waterfall. 


\section{Journal of Software Engineering Ampera}

Vol. 1, No. 3, October 2020 e-ISSN: 2775-2488

https://journal-computing.org/index.php/journal-sea/index

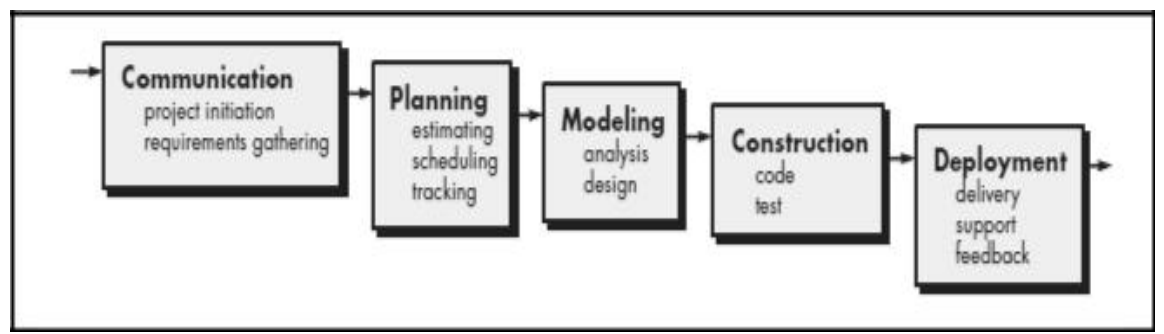

Gambar 1 Waterfal

1) Communication, Langkah ini merupakan analisis terhadap kebutuhan software, dan tahap untuk mengadakan pengumpulan data dengan melakukan pertemuan dengan customer, maupun mengumpulkan data-data tambahan baik yang ada di jurnal, artikel, maupun dari internet.

2) Planning, Proses planning merupakan lanjutan dari proses communication (analysis requirement) yang terdiri dari analisis kebutuhan user dan kebutuhan perangkat lunak. Tahapan ini akan menghasilkan dokumen user requirement atau bisa dikatakan sebagai data yang berhubungan dengan keinginan user dalam pembuatan software, termasuk rencana yang akan dilakukan.

3) Modelling, Proses modeling ini akan menerjemahkan syarat kebutuhan ke sebuah perancangan software yang dapat diperkirakan sebelum dibuat coding. Proses ini berfokus pada rancangan struktur data, arsitektur software, representasi interface, dan detail (algoritma) prosedural. Tahapan ini akan menghasilkan dokumen yang disebut software requirement.

4) Construction, Construction merupakan proses membuat kode. Coding atau pengkodean merupakan penerjemahan desain dalam bahasa yang bisa dikenali oleh komputer. Programmer akan menerjemahkan transaksi yang diminta oleh user. Tahapan inilah yang merupakan tahapan secara nyata dalam mengerjakan suatu software, artinya penggunaan komputer akan dimaksimalkan dalam tahapan ini. Dalam hal proses pengkodingan menggunakan software Macromedia Dreamweaver, database menggunakan mysql dan untuk server menggunakan Apache 2.4 .

5) Deployment, Tahapan ini bisa dikatakan final dalam pembuatan sebuah software atau sistem. Setelah melakukan analisis, desain dan pengkodean maka sistem yang sudah jadi akan digunakan oleh user. 


\section{Journal of Software Engineering Ampera}

Vol. 1, No. 3, October 2020 e-ISSN: 2775-2488

https://journal-computing.org/index.php/journal-sea/index

Kemudian software yang telah dibuat harus dilakukan pemeliharaan secara.

\subsection{Arsitektur Multi-Tier}

Arsitektur Multi-Tier adalah suatu metode yang sangat mirip dengan Three Tier. Bedanya, pada Multi-Tier akan diperjelas bagian UI (User Interface) dan Data Processing.Yang membedakan arsitektur ini adalah dengan adanya Business Logic Server. Database Server dan Bussines Logic Server merupakan bagian dari Data Processing, sedangkan Application Server dan Client/Terminal merupakan bagian dari UI (Tantama : 2013) [1]. Business Logic Server biasanya masih menggunakan bahasa pemrograman terdahulu, seperti COBOL. Karena sampai saat ini, bahasa pemrograman tersebut masih sangat mumpuni sebagai business process. Multi-tier architecture menyuguhkan bentuk threetier yang diperluas dalam model fisik yang terdistribusi. Application server dapat mengakses Application server yang lain untuk mendapat data dari Data server dan mensuplai servis ke client Application. Multi tier application adalah aplikasi yang dibagi menjadi beberapa bagian yang menjalankan fungsi masing-masing. Secara umum, ada tiga bagian utama dari multi tier application [6].

1) Client Side Presentation, Client side presentation mengatur bagaimana aplikasi berinteraksi dengan user. Yang dimaksud dengan interaksi antara lain adalah: bagaimana data ditampilkan, bagaimana fungsi dan fitur aplikasi ditampilkan. Dalam aplikasi berbasis web, client side presentation dibuat dengan bahasa HTML, CSS, dan JavaScript. Beberapa tool yang digunakan untuk membuat client side presentation diantaranya Microsoft Frontpage, Macromedia Dreamweaver, dan sebagainya. Client side presentation berbasis web contohnya adalah tampilan aplikasi email yang kita buka dengan browser.

2) Server Side Business Logic, Server side business logic, sering disebut juga middle tier, adalah bagian yang bertanggung jawab atas cara kerja aplikasi. Di dalamnya kita mengatur bagaimana fungsi dan fitur aplikasi dapat bekerja dengan baik. Dalam aplikasi berbasis web, ada beberapa alternatif yang dapat digunakan, ditentukan oleh jenis platform yang digunakan.

3. Backend Storage, Bagian ini mengatur cara penyimpanan data. Penyimpanan data merupakan materi yang cukup kompleks dalam pembangunan aplikasi. Karena kecepatan, keutuhan, dan keamanan 


\section{Journal of Software Engineering Ampera}

Vol. 1, No. 3, October 2020 e-ISSN: 2775-2488

https://journal-computing.org/index.php/journal-sea/index

data merupakan faktor kritis dalam aplikasi. Ada banyak solusi database yang tersedia di pasaran. Pada umumnya, database yang digunakan bertipe relasional (Relational Database Management System - RDBMS). Manajemen data dilakukan dengan bahasa SQL (Standard Query Language).

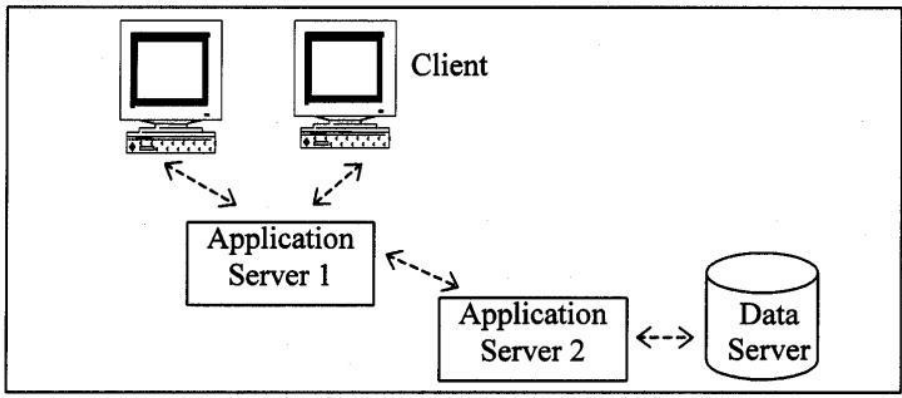

Gambar 2 Multi-tier Client/Server Architecturei

\section{Arsitektur Multi-Tier Sistem Informasi Akademik}

Multi-tier architecture menyuguhkan bentuk three - tier yang diperluas dalam model fisik yang terdistribusi.

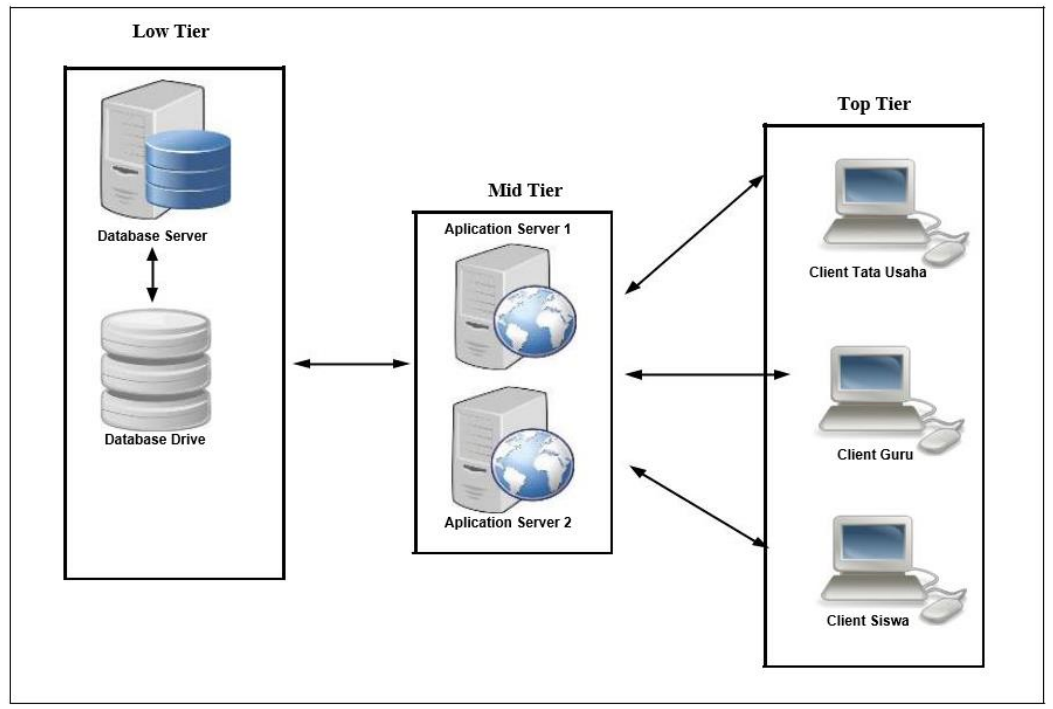

Gambar 3 Arsitektur Multi-Tier Sistem Informasi Akademik 


\section{Journal of Software Engineering Ampera}

Vol. 1, No. 3, October 2020 e-ISSN: 2775-2488

https://journal-computing.org/index.php/journal-sea/index

\section{HASIL DAN PEMBAHASAN}

Berdasarkan tahapan-tahapan perancangan yang telah diuraikan pada babbab sebelumnya, maka pada penelitian ini menghasilkan sistem informasi akademik pada SMA Negeri 7 Prabumulih menggunakan metode Arsitektur Multi-Tier, yang dapat mempermudah pihak sekolah dalam melakukan pencarian dan pengolahan data Akademik dengan memanfaatkan media internet berbasis online.

Hasil dari penelitian ini akan dituangkan dalam bentuk aplikasi yang mana akan dijalankan dijaringan localhost yang nantinya menghasilkan suatu sistem yang dapat mempermudah SMA Negeri 7 Prabumulih khusunya bagian akademik dalam melakukan pengolahan data akademik dengan memberikan informasi mengenai data siswa, data nilai dan data jadwal mengajar secara cepat dan efesien.

\section{1) Alur Proses Arsitektur Multi-Tier pada SIA}

Pada gambar dibawah ini merupakan alur proses multi-tier pada sistem informasi Akdemik, menggambarkan konsep jaringan multi-tier untuk menjalankan sistem informasi akademik terdiri dari 1 database drive, 1 database server, 2 aplication server dan komputer client.

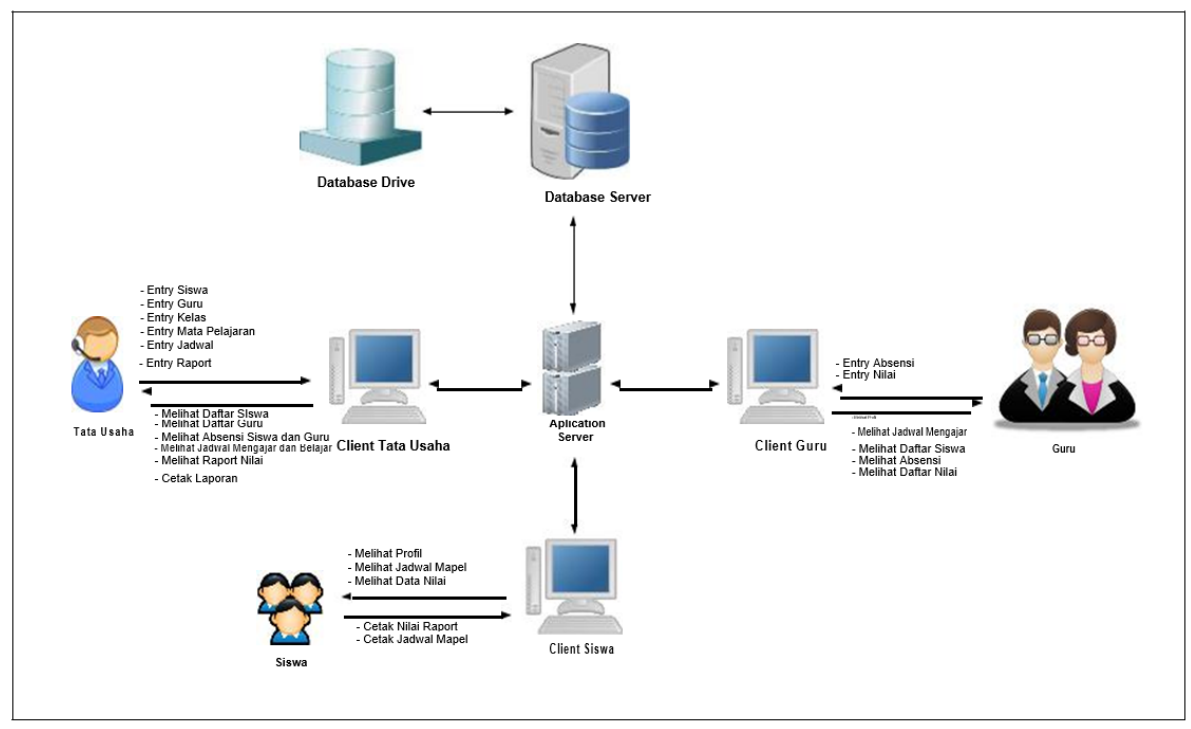

Gambar 4 Alur Proses Arsitektur Multi-Tier pada SIA 


\section{Journal of Software Engineering Ampera}

Vol. 1, No. 3, October 2020 e-ISSN: 2775-2488

https://journal-computing.org/index.php/journal-sea/index

\section{2) Halaman Form Homeindex}

Halaman homeindex merupakan halaman menu utama pada website sistem informasi akademik terdiri dari form profil, pengumuman dan form login user.

\section{SMA NECERI 7 PRABUMULIH \\ Jin. Lingkar Timur, Muara Dua, Prabumulih Timur, Sumatera Selatan}

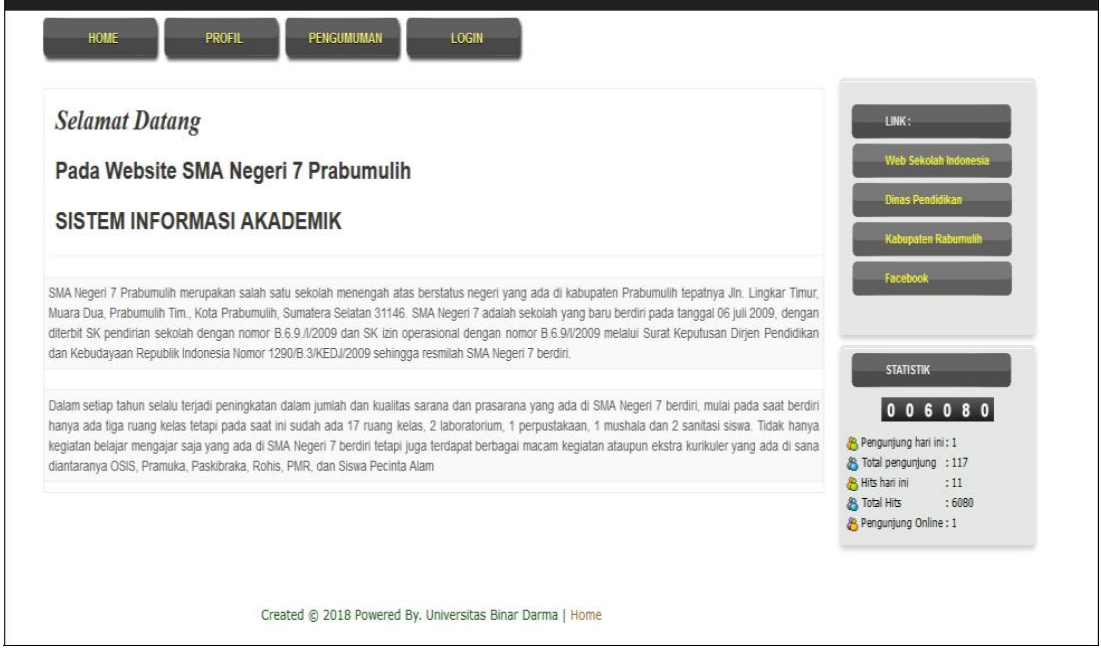

Gambar 5 Halaman Form Homeindex

\section{KESIMPULAN}

Berdasarkan uraian yang telah dikemukakan pada bab-bab sebelumnya, maka kesimpulan yang diambil dalam mencapai tujuan yang diinginkan. Adapun kesimpulan yang dapat diambil adalah sebagai berikut:

1) Pada penelitian ini menghasilkan sistem informasi Akademik pada SMA Negeri 7 Prabumulih dengan menerapkan Arsitektur Multi-Tier, dimana dengan menggunakan Teknologi multi tier ini baik digunakan untuk aplikasi web dengan tugas yang sangat besar dan jumlah pengguna yang banyak. Hal ini dikarenakan teknologi multi tier itu sendiri membagi kerja dari klien dan server menjadi beberapa tier yang tidak menitik beratkan beban proses pada sisi klien maupun server saja.

2) Sistem yang dihasilkan pada penelitian ini yaitu SMA Negeri 7 Prabumulih, dimana sistem ini terdapat 4 Menu user terdiri dari menu untuk tata usaha, menu guru, menu wali kelas dan menu untuk siswa, dapat mempermudah pihak sekolah dalam melakukan pencarian dan 


\section{Journal of Software Engineering Ampera}

Vol. 1, No. 3, October 2020 e-ISSN: 2775-2488

https://journal-computing.org/index.php/journal-sea/index

pengolahan data Akademik dengan menampilkan informasi yang dibutuhkan para siswa/siswi dan guru secara cepat dan efesien.

\section{DAFTAR PUSTAKA}

[1] Satoto, "Analisis Keamanan Sistem Informasi Akademik Berbasis Web Di Fakultas Teknik Universitas Diponegoro", Seminar Nasional Aplikasi Sains dan Teknologi, Yogyakarta. [2009].

[2] Tantama dkk. "Penerapan Arsitektur Multi-Tler dengan DCOM dalam suatu SIstem Informasi". [2013].

[3] Nugroho . "Analisis dan Perancangan Sistem Informasi dengan Metologi Berorientasi Objek". Bandung, Informatika. [2008].

[4] Widi, Restu Kartiko.. "Asas Metodologi Penelitian : Sebuah Pengenalan dan Penuntun Langkah demi Langkah Pelaksanaan Penelitian". Cetakan Pertama. Yogyakarta : Graha Ilmu. [2004].

[5] Roger S. Pressman, P.D. "Rekayasa perangkat lunak". Pendekatan Praktisi. Andi:Yogyakarta. [2010].

[6] Satzinger, B. Jackson, D. Burd. "System Analisis and Design with the Unified Process". USA: Course Technology, Cengage Learning. [2012]. 